\title{
АНАЛІЗ МІНЕРАЛЬНОГО СКЛАДУ РОСЛИННИХ АНТИДІАБЕТИЧНИХ ЗБОРІВ
}

Вступ. Цукровий діабет є глобальною соціальною проблемою у сорері охорони здоров'я, що зумовлена швидкими темпами поширення цього захворювання та розвитком серйозних ускладнень у вигляді діабетичних ангіопатій, які істотно знижують якість і тривалість життя пацієнтів. 3 метою вирішення даної проблеми варто здійснювати оптимізацію існуючої фрармакотерапії, зокрема за допомогою фрітозборів, що зможуть впливати на різні ланки патогенетичного механізму розвитку цукрового діабету та його ускладнень завдяки широкому спектру біологічно активних речовин. У цьому відношенні особливої уваги заслуговують мінеральні речовини, оскільки багато з них бере участь у регулюванні вуглеводного обміну.

Мета дослідження - вивчити мінеральний склад рослинних антидіабетичних зборів, які застосовують у народній медицині для лікування та профрілактики цукрового діабету.

Методи дослідження. Якісний склад та кількісний вміст макро- і мікроелементів визначали методом атомно-абсорбційної спектроскопії з атомізацією у повітряно-ацетиленовому полум'ї.

Результати й обговорення. Під час дослідження було виявлено і встановлено кількісний вміст 5 макро- та 4 мікроелементів у рослинних антидіабетичних зборах № 3, № 4, № 7, № 13, № 19. За результатами дослідження, серед макроелементів найбільший вміст Na в антидіабетичному зборі № 4, $K-B$ антидіабетичних зборах № 4 ma № 7, Fe - № 4 i № 19, Mg - № 3 ma № 19, Ca - № 4 i № 19; серед мікроелементів, які мають значний вплив на розвиток, лікування та перебіг цукрового діабету, найвищий вміст Zn виявлено в антидіабетичних зборах № 13 і № 7, Cr - № 7 ma № 19, Mn - в антидіабетичному зборі № 19, $\mathrm{Cu}$ - № 4.

Висновок. Результати дослідження дозволяють прогнозувати виражену гіпоглікемічну активність антидіабетичних зборів за патогенетичним механізмом впливу.

КЛЮЧОВІ СЛОВА: макроелементи; мікроелементи; рослинні антидіабетичні збори; атомно-абсорбційна спектроскопія.

ВСТУП. Цукровий діабет (ЦД) є серйозною медичною та соціальною проблемою, що набирає глобального масштабу, адже число хворих щороку невпинно зростає в геометричній прогресії, а разом із цим - інвалідизація населення і смертність від тяжких ускладнень [1]. За даними експертів ВОО3, до 2030 р. очікується збільшення кількості хворих в 1,5 раза [1, 2]. В Україні за останні 15 років захворюваність на цю ендокринно-обмінну патологію підвищилася вдвічі [3]. Тому пошук нових лікарських засобів для корекції метаболічних порушень при даному захворюванні - актуальне питання фрармації та медицини. Одним з таких напрямків $є$ застосування фрітопрепаратів, адже вони мають ряд переваг перед синтетичними засобами: мало(с) А. О. Савич, С. М. Марчишин, 2020. токсичні, чинять м'яку дію, можуть тривало використовуватися без суттєвих побічних явищ, добре поєднуються між собою і з лікарськими препаратами, а їх хімічний склад досить різноманітний, що має різнонаправлений механізм впливу на всі ланки патогенезу даного захворювання $[4,5]$.

Особливої уваги заслуговують збори лікарських рослин, адже поєднання лікарської рослинної сировини, що містить різні групи біологічно активних речовин, створює фрітокомпозицію, яка зможе охопити всі патогенетичні механізми розвитку ЦД та його не менш небезпечних ускладнень [6, 7]. Для цього доцільно вивчити фрітохімічний склад досліджуваних рослинних зборів, які широко застосовують у народній медицині. 
Важливе значення в розвитку та перебізі ЦД мають макро- і мікроелементи, оскільки багато з них бере участь у регулюванні вуглеводного обміну [8, 9]. Зокрема, Zn входить до структури інсуліну, збільшує тривалість його цукрознижувальної дії, а стійка гіперглікемія, у свою чергу, призводить до посилення екскреції Zn з організму, погіршує перебіг ЦД та його ускладнень. Десріцит Zn також сприяє розвитку оксидативного стресу та руйнації клітин [9-11]. Cr підвищує активність інсуліну, він $є$ центральним атомом у молекулі гормоноподібної речовини - фрактора засвоєння глюкози (GTF - glucose tolerance factor), що фрункціонує в поєднанні з інсуліном і забезпечує транспортування глюкози через клітинні мембрани. Десріцит $\mathrm{Cr}$ відіграє роль у формуванні діабетичної нейропатії $[10,12,13]$. Існують дані про зв'язок між розвитком ЦД та вмістом в організмі Se. Недостатність в організмі Mn може сприяти розвитку ЦД 2 типу. $\mathrm{Cu}, \mathrm{Fe}, \mathrm{Mg}$ беруть участь у синтезі протеїнів та ензимів, що необхідні для нормального обміну речовин [10, $11,13]$.

Мета дослідження - вивчити мінеральний склад рослинних антидіабетичних зборів, які застосовують у народній медицині для лікування та профрілактики цукрового діабету.

МЕТОДИ ДОСЛІДЖЕННЯ. Під час дослідження було використано рослинну сировину, заготовлену в червні - серпні 2019 р. на Тернопільщині й у Карпатах (листя Vaccinium myrtillus) (Україна). Після збирання сировину сушили, подрібнювали та приводили, відповідно, до стандартного стану [14]. Рослинні збори формували згідно з їх компонентним складом (табл. 1) [15].

Якісний склад і кількісний вміст макро- та мікроелементів у досліджуваних антидіабетичних зборах визначали на базі відділу радіохімії і радіоекології НДІ хімії при Харківському національному університеті імені В. Н. Каразіна за сприяння завідувача відділу А. П. Краснопьорової. Дослідження проводили методом атомно-абсорбційної спектроскопії з атомізацією у повітряно-ацетиленовому полум'ї [16].

Пробопідготовку зразків сировини здійснювали методом сухого озолення, яке полягало у спалюванні досліджуваної подрібненої сировини у мусеельній печі при температурі $450-500{ }^{\circ} \mathrm{C}$ упродовж 6 год [16].

Таблиця 1 - Компонентний склад рослинних антидіабетичних зборів

\begin{tabular}{|c|c|c|c|}
\hline & Рослинний збір & Рослинна сировина & Вміст сировини у зборі, г \\
\hline & № 3 & $\begin{array}{l}\text { Urticae folia } \\
\text { Cichorii radices } \\
\text { Rosae majalis fructus } \\
\text { Elymi repens rhizomata } \\
\text { Taraxaci radicis }\end{array}$ & $\begin{array}{l}26,32 \\
26,32 \\
21,05 \\
15,79 \\
10,52 \\
\end{array}$ \\
\hline & & & Разом: 100 \\
\hline & № 4 & $\begin{array}{l}\text { Arctii lappae radicis } \\
\text { Elymi repens rhizomata } \\
\text { Maydis style cum stigmatis } \\
\text { Helichrysi arenarii flores } \\
\text { Rosae majalis fructus } \\
\end{array}$ & $\begin{array}{l}26,32 \\
26,32 \\
21,05 \\
15,79 \\
10,52 \\
\end{array}$ \\
\hline & & & Разом: 100 \\
\hline 焉 & № 7 & $\begin{array}{l}\text { Inulae rhizomata rt radices } \\
\text { Helichrysi arenarii flores } \\
\text { Maydis style cum stigmatis } \\
\text { Origani herba } \\
\text { Rosae majalis fructus } \\
\text { Taraxaci radicis }\end{array}$ & $\begin{array}{l}10,00 \\
20,00 \\
20,00 \\
20,00 \\
20,00 \\
10,00\end{array}$ \\
\hline 疋 & & & Разом: 100 \\
\hline 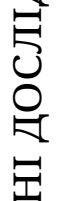 & № 13 & $\begin{array}{l}\text { Cichorii radices } \\
\text { Elymi repens rhizomata } \\
\text { Helichrysi arenarii flores } \\
\text { Rosae majalis fructus } \\
\text { Maydis style cum stigmatis }\end{array}$ & $\begin{array}{l}26,32 \\
26,32 \\
21,05 \\
15,79 \\
10,52\end{array}$ \\
\hline 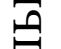 & & & Разом: 100 \\
\hline 声 & № 19 & $\begin{array}{l}\text { Urticae folia } \\
\text { Taraxaci radicis } \\
\text { Myrtilli lolia } \\
\text { Rosae majalis fructus } \\
\text { Menthae folia }\end{array}$ & $\begin{array}{l}20,00 \\
20,00 \\
20,00 \\
20,00 \\
20,00 \\
\end{array}$ \\
\hline 0 & & & Разом: 100 \\
\hline 82 & & ISSN 2410-681X. Мед & на хімія. 2020. Т. 22.1 \\
\hline
\end{tabular}


Атомно-абсорбційний аналіз проводили на атомно-абсорбційному спектросотометрі C-115 ПК. Атомізацію хімічних елементів здійснювали у повітряно-ацетиленовому полум'ї при довжині хвилі 220-340 нм. Калібрувальну криву будували в залежності середніх значень поглинання розчинів порівняння солей металів від їх концентрації. Для кожного елемента було досягнуто строгу лінійність із використанням п'яти калібрувальних розчинів в інтервалі вимірюваних концентрацій. Максимальна відносна похибка вимірювання при довірчій імовірності 0,95 і п'яти паралельних вимірюваннях становила $\pm 5 \%$.

Вміст Са та Mg у досліджуваних об'єктах визначали титраметричним методом. Вміст елементів $\mathrm{K}$ i Na вимірювали в емісійному режимі [16].

РЕЗУЛЬТАТИ Й ОБГОВОРЕННЯ. РеЗУЛЬТАТИ визначення кількісного вмісту макро- і мікроелементів у зразках рослинних антидіабетичних зборів наведено в таблиці 2.

Таблиця 2 - Вміст макро- та мікроелементів у рослинних антидіабетичних зборах

\begin{tabular}{|c|c|c|c|c|c|c|}
\hline \multirow{3}{*}{ № 3/п } & \multirow{2}{*}{ Назва } & \multicolumn{5}{|c|}{ "Рослинний антидіабетичний збір } \\
\hline & & № 3 & № 4 & № 7 & № 13 & № 19 \\
\hline & масова частка золи, \% & 5,9 & 6,0 & 7,1 & 5,1 & 6,7 \\
\hline \multicolumn{7}{|c|}{ Вміст повітряно-сухої сировини, мг/кг } \\
\hline 1 & Натрій (Na) & 249,0 & 1086,0 & 88,0 & 224,0 & 235,0 \\
\hline 2 & Калій (K) & 12964,0 & 18556,0 & 19403,0 & 16620,0 & 12496,0 \\
\hline 3 & Кальцій (Са) & 250,0 & 333,0 & 204,0 & 98,0 & 356,0 \\
\hline 4 & Магній (Mg) & 1382,0 & 568,0 & 833,0 & 495,0 & 2296,0 \\
\hline 5 & Ферум (Fe) & 168,0 & 504,0 & 207,0 & 222,0 & 378,0 \\
\hline 6 & Купрум (Cu) & 14,2 & 18,0 & 11,1 & 12,5 & 10,5 \\
\hline 7 & Цинк (Zn) & 23,6 & 22,3 & 32,6 & 34,9 & 21,4 \\
\hline 8 & Манган (Mn) & 19,0 & 25,3 & 17,1 & 17,3 & 59,6 \\
\hline 9 & Хром $(\mathrm{Cr})$ & $H / B$ & $H / B$ & 5,0 & $H / B$ & 3,3 \\
\hline
\end{tabular}

Примітка. н/в - елемент, якого не виявлено у досліджуваному об'єкті.

За результатами дослідження, серед мікроелементів, які мають значний вплив на розвиток, лікування та перебіг ЦД, найвищий вміст Zn виявлено в антидіабетичних зборах № 13 (34,9 мг/кг) i № 7 (32,6 мг/кг), Cr - № 7 (5,0 мг/кг) та № 19 (3,3 мг/кг), Mn - в антидіабетичному зборі № 19 (59,6 мг/кг), Сu - № 4 (18,0 мг/кг); серед макроелементів найбільший вміст $\mathrm{Na}$ в антидіабетичному зборі № 4 (1086,0 мг/кг), К - В антидіабетичних зборах № 4 (18556,0 мг/кг) та № 7 (19403,0 мг/кг), $\mathrm{Fe}$ - № 4 (504,0 мг/кг) i № 19 (378,0 $\mathrm{mr} / \mathrm{kr}), \mathrm{Mg}$ - № 3 (1382,0 мг/кг) та № 19 (2296,0 мг/кг), Сa - № 4 (333,0 мг/кг) i № 19 (356,0 мг/кг). Досить високий вміст макро- і мікроелементів у досліджуваних фітокомпозиціях свідчить про перспективність їх застосування

\section{СПИСОК ЛІТЕРАТУРИ}

1. American Diabetes Association, Standards of Medical Care in Diabetes. - Diabetes Care. - 2017. 40 (1). - $142 \mathrm{p}$.

2. International Diabetes Federation. IDF Diabetes Atlas. -2019 . -9 th edition, Brussels, Belgium.

3. Результати дослідження "Цукровий діабет у практиці лікаря". - 2019. - Аксемедін.
3 метою оптимізації фрармакотерапії ЦД та його ускладнень.

ВИСНОВКИ. Досліджувані рослинні антидіабетичні збори № 3, № 4, № 7, № 13 та № 19 містять необхідні мінерали в достатній кількості для прояву гіпоглікемічної активності. Результати вивчення якісного складу та кількісного вмісту елементів, що містяться в рослинних антидіабетичних зборах, дозволяють зробити висновок про гіпоглікемічну активність за патогенетичним механізмом впливу. Це свідчить про доцільність подальшого вивчення даних зборів як перспективних фрітозасобів для лікування та профрілактики цукрового діабету і діабетичних ангіопатій.

4. Natural phyto-bioactive compounds for the treatment of type 2 diabetes: Inflammation as a Target I S. Gothai, P. Ganesan, S. Y. Park [et al.] // Nutrients. 2016. - 8 (8). - $461 \mathrm{p}$.

5. Phytotherapy in the management of diabetes: A review. Molecules / P. Governa, G. Baini, V. Borgonetti [et al.]. - 2018. - Basel, Switzerland. - 23(1). - 105 p. 
6. Oh Y. S. Role of bioactive food components in diabetes prevention: effects on Beta-cell function and preservation/Y. S. Oh, H. S. Jun // Nutrition and Metabolic Insights. - 2014. - 7. - P. 51-59.

7. The role of medicinal plants in the treatment of diabetes: a systematic review /W. Kooti, M. Farokhipour, Z. Asadzadeh [et. al.] // Electronic Physician. - 2016. 8 (1). - P. 1832-1842.

8. Anti-diabetic effect of a preparation of vitamins, minerals and trace elements in diabetic rats: a gender difference / M. Sárközy, V. Fekete, G. Szűcs [et al.] // BMC Endocrine Disorders. - 2014. - 14. - 72 p.

9. Antioxidant role of zinc in diabetes mellitus / K. J. Cruz, A. R. de Oliveira, D. Marreiro // World Journal of Diabetes. - 2015. - 6 (2). - P. 333-337.

10 . Variation in macro and trace elements in progression of type 2 diabetes / K. Siddiqui, N. Bawazeer, S. S. Joy // The Scientific World Journal. - 2014. P. 461-591.

11. The relationship between dietary, serum and hair levels of minerals ( $\mathrm{Fe}, \mathrm{Zn}, \mathrm{Cu}$ ) and glucose metabolism indices in obese type 2 diabetic patients / E. Król, P. Bogdański, J. Suliburska [et al.] // Biological Trace Element Research. - 2019. - 189 (1). - P. 34-44.

12. A systematic review on the implication of minerals in the onset, severity and treatment of periodontal disease / A. Varela-López, F. Giampieri, P. Bullón [et al.] // Molecules (Basel, Switzerland). - 2016. - 21 (9). P. 1183.

13. Role of minerals and trace elements in diabetes and insulin resistance / P. Dubey, V. Thakur, M. Chattopadhyay // Nutrients. - 2020. - 12 (6). - P. 1864.

14. WHO Guidelines on Good Agricultural and Mixture Practices (GACP) for Medicinal Plants. - World Health Organization, Geneva. - 2003. - 72 p.

15. Товстуха $€$. С. Золоті рецепти української народної медицини / Є. С. Товстуха. - К. : КМ, 2010. $550 \mathrm{c}$.

16. Методы биохимических исследований (липидный и энергетический обмен) : учеб. пособ. / под ред. М. И. Прохоровой. - Л. : Изд-во Ленингр. ун-та, 1982. 272 c.

\section{REFERENCES}

1. American Diabetes Association, Standards of Medical Care in Diabetes (2017). Diabetes Care, 40 (1), 142.

2. (2019). International Diabetes Federation. IDF Diabetes Atlas, 9th edition. Brussels, Belgium.

3. (2019). The editors of Axemedin. Rezultaty doslidzhennia "Tsukrovyi diabet u praktytsi likaria" [The results of the study "Diabetes in the practice of the doctor"]. Kyiv: Axemedin [in Ukrainian].

4. Gothai, S., Ganesan, P., Park, S. Y., Fakurazi, S., Choi, D. K., \& Arulselvan, P. (2016). Natural phytobioactive compounds for the treatment of type 2 diabetes: Inflammation as a target. Nutrients, 8 (8), 461.

5. Governa, P., Baini, G., Borgonetti, V., Cettolin, G., Giachetti, D., Magnano, A. R., Miraldi, E., \& Biagi, M. (2018). Phytotherapy in the management of diabetes: A review. Molecules (Basel, Switzerland), 23 (1), 105.

6. Oh, Y.S., \& Jun, H.S. (2014). Role of bioactive food components in diabetes prevention: effects on Betacell function and preservation. Nutrition and Metabolic Insights, 7, 51-59.

7. Kooti, W., Farokhipour, M., Asadzadeh, Z., AshtaryLarky, D., \& Asadi-Samani, M. (2016). The role of medicinal plants in the treatment of diabetes: a systematic review. Electronic Physician, 8 (1), 1832-1842.

8. Sárközy, M., Fekete, V., Szúcs, G., Török, S., Szúcs, C., Bárkányi, J., Varga, Z. V., Földesi, I., Csonka, C., Kónya, C., Csont, T., \& Ferdinandy, P. (2014). Antidiabetic effect of a preparation of vitamins, minerals and trace elements in diabetic rats: a gender difference. BMC Endocrine Disorders, 14, 72.
9. Cruz, K.J., de Oliveira, A.R., \& Marreiro, D. (2015) Antioxidant role of zinc in diabetes mellitus. World Journal of Diabetes, 6 (2), 333-337.

10. Siddiqui, K., Bawazeer, N., \& Joy, S.S. (2014). Variation in macro and trace elements in progression of type 2 diabetes. The Scientific World Journal, 2014, 461591.

11. Król, E., Bogdański, P., Suliburska, J., \& Krejpcio, Z. (2019). The relationship between dietary, serum and hair levels of minerals ( $\mathrm{Fe}, \mathrm{Zn}, \mathrm{Cu}$ ) and glucose metabolism indices in obese type 2 diabetic patients. Biological Trace Element Research, 189 (1), 34-44.

12. Varela-López, A., Giampieri, F., Bullón, P., Battino, M., \& Quiles, J. L. (2016). A systematic review on the implication of minerals in the onset, severity and treatment of periodontal disease. Molecules (Basel, Switzerland), 21 (9), 1183.

13. Dubey, P., Thakur, V., \& Chattopadhyay, M. (2020). Role of minerals and trace elements in diabetes and insulin resistance. Nutrients, 12 (6), 1864. Retrieved from: https://doi.org/10.3390/nu12061864

14. (2003). WHO Guidelines on Good Agricultural and Mixture Practices (GACP) for Medicinal Plants. World Health Organization. Geneva.

15. Tovstuha, Ye.S. (2010). Zoloti retsepty ukrainskoi narodnoi medytsyny [Golden recipes of Ukrainian folk medicine]. Kyiv: Kraina mrii [in Ukrainian].

16. Prohorova, M.I. (1982). Metody biokhimicheskikh issledovaniy (lipidnyy i energeticheskiy obmen) [Methods of biochemical studies (lipid and energy metabolism)]. Leningrad: Izdatelstvo Leningradskogo universiteta [in Russian]. 


\section{АНАЛИЗ МИНЕРАЛЬНОГО СОСТАВА РАСТИТЕЛЬНЫХ ПРОТИВОДИАБЕТИЧЕСКИХ СБОРОВ}

\section{Резюме}

Вступление. Сахарный диабет является глобальной социальной проблемой в сфрере здравоохранения, что обусловлена быстрыми темпами распространения этого заболевания и развитием серьезных осложнений в виде диабетических ангиопатий, которые существенно снижают качество и продолжительность жизни пациентов. С целью решения данной проблемы следует осуществлять оптимизацию существующей фрармакотерапии, в частности с помощью фритосборов, которые смогут влиять на различные звенья патогенетического механизма развития сахарного диабета и его осложнений благодаря широкому спектру биологически активных веществ. В этом отношении особого внимания заслуживают минеральные вещества, поскольку многие из них участвуют в регулировании углеводного обмена.

Цель исследования - изучить минеральный состав растительных противодиабетических сборов, применяемых в народной медицине для лечения и профилактики сахарного диабета.

Методы исследования. Качественный состав и количественное содержание макро- и микроэлементов определяли методом атомно-абсорбционной спектроскопии с атомизацией в воздушно-ацетиленовом пламени.

Результаты и обсуждение. В ходе исследования было выявлено и установлено количественное содержание 5 макро- и 4 микроэлементов в растительных противодиабетических сборах № 3, № 4, № 7, № 13, № 19. По результатам исследования, среди макроэлементов наибольшее содержание Na в противодиабетическом сборе № 4, K - в противодиабетических сборах № 4 и № 7, Fe - № 4 u № 19 , Mg - № 3 и № 19, Са - № 4 и № 19; среди микроэлементов, которые оказывают значительное влияние на развитие, лечение и течение сахарного диабета, наивысшее содержание Zn выявлено в противодиабетических сборах № 13 и № 7, Cr - № 7 и № 19, Mn - в противодиабетическом сборе № 19, $\mathrm{CU}$ - № 4.

Вывод. Результаты исследования позволяют прогнозировать выраженную гипогликемическую активность противодиабетических сборов по патогенетическому механизму воздействия.

КЛЮЧЕВЫЕ СЛОВА: макроэлементы; микроэлементы; растительные противодиабетические сборы; атомно-абсорбционная спектроскопия.

A. O. Savych, S. M. Marchyshyn HORBACHEVSKY TERNOPIL NATIONAL MEDICAL UNIVERSITY

\section{ANALYSIS OF THE MINERAL COMPOSITION OF HERBAL ANTIDIABETIC MIXTURES}

\section{Summary}

Introduction. Diabetes mellitus is a global social health problem due to the rapid spread of the disease and the development of serious complications in the form of diabetic angiopathies, which significantly reduce the quality and life expectancy of patients. In order to solve this problem, it is necessary to optimize the existing pharmacotherapy, in particular through phytomixtures, that will be able to influence on different links of the pathogenetic mechanism of development of diabetes mellitus and its complications due to a wide range of biologically active substances. In this regard, minerals deserve special attention, as many of them are involved in the regulation of carbohydrate metabolism.

The aim of the study - to learn the mineral composition of the herbal mixtures, which are used in folk medicine for the prevention and treatment of diabetes mellitus.

Research Methods. Determination of the qualitative composition and quantitative content of macro- and microelements was performed by atomic absorption spectroscopy with atomization in an air-acetylene flame. 
Results and Discussion. During the study, it was detected and established the quantitative content of 5 macro- and 4 microelements in the herbal antidiabetic mixtures No. 3, No. 4, No. 7, No. 13 and No. 19. According to the results of the study, it was found the highest content of Na in the herbal antidiabetic mixture No. 4; K - No. 4 and No. 7; Fe - No. 4 and No. 9; Mg - No. 3 and No. 19; Ca - No. 4 and No. 19. Among the microelements, which have a significant impact on the development, treatment and course of diabetes, it was established the highest content of $\mathrm{Zn}$ in the herbal antidiabetic mixture No. 13 and No. 7; Cr - No. 7 and No. 19; Mn - No. 19; $\mathrm{Cu}-$ No. 4.

Conclusions. The results of the study allow predict the pronounced hypoglycemic activity of antidiabetic mixtures by the pathogenetic mechanism of action.

KEY WORDS: macroelements; microelements; herbal antidiabetic mixtures; atomic absorption spectroscopy.

Отримано 18.05.20

Адреса для листування: С. М. Марчишин, Тернопільський національний медичний університет імені І. Я. Горбачевського МОз України, майдан Волі, 1, Тернопіль, 46001, Україна, e-mail: marchyshyn@tdmu.edu.ua. 